\title{
KESENIAN MADIHIN DI BANJARMASIN KALIMANTAN SELATAN DALAM TINJAUAN AKSIOLOGI DAN RELEVANSINYA TERHADAP PENDIDIKAN KARAKTER
}

\author{
M. Budi Zakia Sani \\ Universitas Negeri Yogyakarta \\ E-mail: mbudizakiasani1991@gmail.com
}

\begin{abstract}
Abstrak
Penelitian ini bertujuan untuk mengungkapkan; (1) bentuk, struktur, dan fungsi kesenian Madihin, (2) nilai-nilai aksiologis yang terkandung di dalam kesenian Madihin, dan (3) relevansi nilai-nilai yang terkandung dalam kesenian Madihin terhadap pendidikan karakter. Penelitian ini menggunakan jenis penelitian kualitatif dengan pendekatan etnografi.. Objek material dalam penelitian ini adalah kesenian Madihin di Banjarmasin. Pengumpulan data dalam penelitian ini menggunakan teknik observasi, wawancara, dan dokumentasi. Analisis data menggunakan model Miles dan Huberman yang meliputi reduksi data, penyajian data, dan penarikan kesimpulan. Hasil penelitian menunjukkan bahwa kesenian Madihin mengandung hierarki nilai moralitas yang meliputi; (1) nilai religiusitas, (2) nilai toleransi, (3) nilai disiplin, (4) nilai kerja keras, (5) nilai kreatif, (6) nilai komunikatif, (7) nilai tanggung jawab, dan (8) nilai cinta tanah air. Nilai-nilai tersebut memiliki relevansi dengan nilai pendidikan karakter. Nilai tersebut bisa dijadikan sebagai sarana untuk membangun pendidikan karakter di Indonesia.
\end{abstract}

Kata kunci: kesenian Madihin, aksiologi, dan pendidikan karakter

\section{MAHIDIN ART IN BANJARMASIN SOUTH KALIMANTAN IN THE AXIOLOGY PERSPECTIVE AND THE RELEVANCE TO CHARACTER EDUCATION}

\begin{abstract}
This research aims to reveal; (1) forms, structures, and functions of Madihin Art, (2) the axiological value of Madihin art, and (3) relevance the value of Madihin art to character education. This research is uses qualitative research with ethnography approach. The material object of this research was Madihin art in Banjarmasin. The data were collected through observation, interviews, and documentation. The data were analyzed using Miles and Huberman framework, which covers data reduction, presentation, and conclusion drawing. The results show that Madihin art contains morality value hierarcy, consisting of; (1) religiousity, (2) tolerance, (3) discipline, (4) hardworking, (5) creativity, (6) communicativeness, (7) responsibility, and (8) patriotism. Those values can be made as a medium of supporting character education in Indonesia.
\end{abstract}

Keywords: Madihin art, axiology, character education

\section{PENDAHULUAN}

Madihin adalah kesenian tradisi suku banjar, Kalimantan Selatan. Madihin berasal dari kata madah, sejenis puisi lama dalam sastra
Indonesia, karena ia menyanyikan syair-syair yang berasal dari kalimat akhir yang bersamaan bunyi. Madah bisa juga diartikan sebagai katakata pujian (Bahasa Arab), hal ini bisa dilihat 
dari kalaimat-kalimat dalam bait-bait madihin yang kadang kala berupa pujian-pujian (Thaha, 2014:23-24). Pendapat lain mengatakan bahwa madihin juga berasal dari bahasa Banjar, yaitu papadah atau mamadahi atau dalam Bahasa Indonesia berarti memberikan nasihat (Rafiek, 2012:106).

Pada tahun 2014 lalu, Kesenian madihin telah ditetapkan oleh UNESCO sebagai Warisan Budaya Tak Benda milik Indonesia yang berasal dari Kalimantan Selatan. Ini merupakan bukti bahwa kesenian ini merupakan kesenian yang sudah diakui keberadaannya. Hal ini menegaskan bahwa kesenian ini merupakan kesenian yang perlu dilestarikan dan dikembangkan. Salah satu caranya adalah melakukan penelitian ini sebagai sebuah bentuk perhatian dan kepedulian saya terhadap eksistensi kesenian ini untuk terus dijaga dan melestarikannya sebagai kekayaan khasanah bangsa Indonesia yang menjadikan identitas kita terhadap dunia.

Namun dalam kenyataannya keberadaan kesenian madihin pada saat ini tidak harmoni dengan pengakuan UNESCO tersebut, kesenian madihin kurang mendapatkan minat dari generasi muda. Hanya sedikit yang berminat untuk mempelajari dan melestarikan kesenian ini. Oleh karena itu sangat penting untuk diketahui dan diapresiasi lebih jauh di kalangan masyarakat Banjarmasin secara luas. Seniman yang masih menggeluti kesenian tersebut sampai saat ini jumlahnya bisa dihitung dengan jari. Dan inilah yang menjadi salah satu alasan yang melatar belakangi penelitian ini.

Perkembangan zaman yang berupa kemajuan ilmu pengetahuan dan teknologi menjadikan informasi tersebar dengan cepat. Media penyebaran informasi di antaranya internet dan televisi dapat diakses oleh semua orang, termasuk anak-anak. Mirisnya, informasi yang berupa perkelahian, bullying, tawuran antarpeserta didik, pacaran bebas, dan pemerkosaan sering terdengar belakangan ini. Kejadian tersebut sering terjadi bukan hanya pada kalangan dewasa namun lebih mirisnya terjadi di kalangan anak usia sekolah. Alasan terbesar adanya kejadian ini adalah karena kurangnya pengembangan nilai-nilai karakter dalam diri peserta didik (Mardikarini dan Suwarjo, 2016:261).

UU No. 20 Tahun 2003 bab II pasal 3 menyebutkan bahwa tujuan dari pendidikan nasional adalah mengembangkan dan mencerdaskan kehidupan bangsa. Menilik Program Nawacita Kabinet Kerja Jokowi-JK nomor. 8 yang menyebutkan bahwa Bangsa Indonesia harus melakukan revolusi mental dengan memperbaiki pendidikan karakter bangsa secara menyeluruh dan komprehensif.

Tujuan pendidikan nasional dan program Nawacita di atas menunjukan bahwa pentingnya moralitas dalam proses pembentukan karakter seorang manusia dan bangsa secara keseluruhan. Hal ini merupakan permasalahan yang sedang dihadapi dunia pendidikan di Indonesia saat ini. Moralitas merupakan hal yang sangat penting dalam kelangsungan kehidupan suatu bangsa. Unsur pembentukan moralitas yang baik adalah tujuan bagi dunia pendidikan itu sendiri. Apalagi jika sudah membicarakan tentang pendidikan karakter.

Presiden Joko Widodo dalam Harian Kompas Edisi Jumat 27 Januari 2017 menyatakan bahwa salah satu fokus pemerintah di bidang pendidikan saat ini adalah pembangunan karakter siswa dengan berbagai nilai positif khas bangsa Indonesia. Karakter yang kuat diperlukan agar siswa tidak kehilangan jati diri di era persaingan global. Pembangunan karakter penting karena saat ini kualitas interaksi sosial semakin menurun, di banyak sendi kehidupan terjadi pergeseran nilai-nilai positif bangsa. Hal ini menegaskan bahwa pentingnya pembangunan terhadap pendidikan karakter merupakan tugas bersama yang menjadi kewajiban setiap elemen pemilik bangsa ini. Disinilah peran yang tepat bagi pendidikan seni untuk berkontribusi terhadap kemajuan pendidikan di Indonesia dengan mewujudkan pendidikan karakter yang bersumber nilai-nilai dalam kearifan lokal daerah di Indonesia, yang salah satunya merupakan kesenian madihin yang berasal dari Banjarmasin Kalimantan Selatan.

Hal ini sesuai dengan kutipan pada berita Harian Kompas edisi Jumat 20 Januari 2017 yang menyebutkan bahwa nilai-nilai kearifan 
lokal yang dianggap penting pada suatu masyarakat di daerah yang dapat dimanfaatkan untuk memperkaya kurikulum nasional. Pemanfaatan nilai-nilai lokal maupun kearifan lokal dalam kehidupan sehari-hari masyarakat pada pembelajaran bukan hanya untuk membentuk karakter, tetapi juga membantu mempermudah penguasaan kompetensi siswa dalam pembelajaran. Oleh karena itu, kesenian madihin sebagai salah satu kearifan lokal yang berasal dari Kalimantan Selatan merupakan salah satu sumber nilai-nilai yang akan menopang pendidikan karakter pada proses pendidikan di Indonesia.

\section{METODE}

Pendekatan penelitian yang digunakan adalah dengan menggunakan metode penelitian kualitatif dengan pendekatan etnografi. Metode ini digunakan untuk meneliti pada kondisi objek yang alamiah, yaitu objek yang berkembang apa adanya tanpa manipulasi terhadap data penelitian dan keberadaan penelitian ini tidak mempengaruhi objek tersebut. Penelitian kualitatif bersifat deskriptif, yaitu mengumpulkan data dengan cara terjun langsung ke dalam objek penelitian tersebut, data-data yang dikumpulkan yaitu berupa gambar-gambar, dan wawancara langsung dengan narasumber. Seperti menurut Flick (2002:1) dalam bukunya menyebutkan bahwa:

Qualitative research is establishing it self in the social sciences and in psychology. There is now available a great variety of specific methods each of which starts from different premises and persues different aims. Each methods is based on a specific understanding of its object.

Paparan di atas menyatakan bahwa penelitian kualitatif itu berdiri sendiri dalam sebuah skenario penelitian. Penelitian kualitatif sekarang ini dapat digunakan menjadi bagian yang besar dalam setiap metode yang spesifik sebagai dasar pemikiran yang berbeda dan mengikuti tujuan yang berbeda pula. Dengan menggunakan penelitian kualitatif ini maka data yang didapat akan lebih lengkap, mendalam, kredibel, dan bermakna mengenai objek penelitian untuk mengatahui Kesenian Madihin Di Banjarmasin Kalimantan Selatan dalam Tinjauan Aksiologi dan Relevansinya Terhadap Pendidikan Karakter. Sehingga dengan menggunakan metode kualitatif inilah objek penelitian ini dapat untuk dianalisis dan diinterpretasi datanya ke dalam bentuk penulisan data penelitian.

Waktu penelitian meliputi tahap : pra penelitian (survei, penentuan judul dan lokasi penelitian, dan penyusunan proposal penelitian, juni sampai oktober 2016), pelaksanaan penelitian (pengambilan data, wawancara, dokumentasi, pengumpulan literartur, november 2016 sampai januari 2017), penyusunan laporan (tahap analisis data yang meliputi reduksi data, pengolahan data, dan penyajian data, kesimpulan, januari sampai april 2017).

Lokasi penelitian dilakukan di Kota Banjarmasin, Kalimantan Selatan. Alasan pemilihan lokasi ini untuk dijadikan lokasi penelitian adalah karena lokasi ini merupakan Ibukota Kalimantan Selatan yang merupakan barometer perkembangan kesenian madihin. Oleh karena itu lokasi penelitian ini berfokus di Kota Banjarmasin Kalimantan Selatan.

Subjek atau instrumen penelitian dalam penelitian ini adalah peneliti sendiri yang bertindak sebagai pemeran utama dalam proses penelitian. Peneliti merupakan alat utama yang menetukan data yang dihasilkan, hingga pada tahap analisis data dan kesimpulan penelitian.

Teknik pengumpulan data meliputi teknik observasi, wawancara dan dokumentasi. Observasi dilakukan untuk mencari tahu tentang gambaran objek penelitian di lapangan. Sedangkan wawancara dan dokumentasi dilakukan untuk merekam dan menangkap kejadian serta fenomena yang terdapat dalam penelitian.

Teknik analisis data menggunakan model Miles dan Huberman yang meliputi tiga tahapan. Pertama, reduksi data yang mana dalam proses ini dilakukan penegumpulan data yang sebanyak-banyaknya kemudian data di seleksi dan dikurangi berdasarkan tingkat kepentingan dan keperluannya. Kedua, penyajian data, data 
yang sudah direduksi selanjutnya akan disajikan dan ditampilkan agar mempermudah untuk menganalisis tahapan berikutnya. Setelah data disajikan kemudia dilakukan tahapan terakhir yaitu verifikasi data atau penarikan kesimpulan yang mana dalam proses ini terdapat tahap cek dan ricek lagi terhadap data yang sudah dianalisis, kemudian tahap akhirnya dilakukan penarikan kesimpulan atas data yang sudah dianalisis tadi.

\section{HASIL DAN PEMBAHASAN \\ Bentuk Penyajian Kesenian Madihin}

Bentuk kesenian madihin adalah syair dan pantun, dan yang disampaikan dalam madihin adalah berupa syair dan pantun (Thaha dan Sanderta, 2014:23). Kawi, Jarkasi, dan Zakiah (1995: 6) menyatakan bahwa irama dan pepantunan yang disampaikan oleh pamamdihinan berbentuk puisi dan sastra lisan madihin berbentuk syair dan pantun.

Jarkasi (2004:2-4) menyatakan bahwa madihin adalah tuturan papantunan. menyatakan bahwa bentuk madihin adalah pantun. Jarkasi (2004:8) menyatakan bahwa bentuk madihin ada batawak pantun dan syair. Seman (2015:5) menyatakan bahwa bentuk kesenian madihin adalah berupa syair. Berdasarkan beberapa penjelasan di atas dapat disimpulkan bahwa bentuk dari kesenian madihin adalah pantun dan syair yang menjadi satu seni pertunjukan secara utuh.

\section{Bentuk Pementasan Kesenian Madihin 1) Tunggal}

Pementasan madihin secara tunggal adalah salah satu dari cara pementasan dalam kesenian madihin. Dalam pementasan kesenian madihin secara tunggal seorang seniman madihin dituntut memiliki kecerdasan yang ekstra dalam setiap penampilannya. Oleh karena itu, melakukan pementasan yang berdurasi sekitar 10 menit atau lebih diperlukan kekuatan pernafasan, keahlian bersyair dan berlagu yang terlatih dan mumpuni pula. Jika dibandingkan dengan madihin berpasangan masih bisa saja secara bergantian untuk masing-masing menarik nafas saat menuju syair-syair selanjutnya. Untuk melihat contoh pementasan madihin tunggal dapat dilihat gambar sebagai berikut :

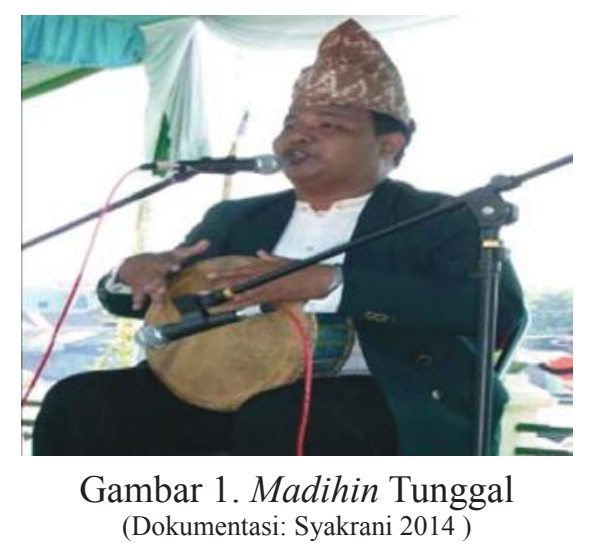

\section{2) Berpasangan}

Kesenian madihin juga bisa dibawakan secara berpasangan atau lebih dari satu orang. Madihin yang dibawakan oleh lebih dari satu orang akan membuat madihin menjadi lebih menarik dan fleksibel. Madihin berpasangan biasanya bisa dilakukan antara laki-laki dan perempuan, atau laki-laki dengan laki-laki, maupun perempuan dengan perempuan, sesuai dengan keperluan pertunjukan. Berikut merupakan contoh gambar pementasan madihin secara berpasangan.

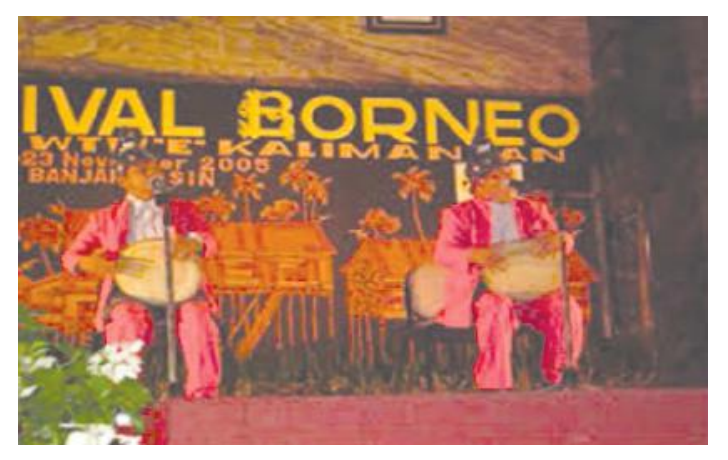

Gambar 2. Madihin Berpasangan (Dokumentasi :John Tralala, 2005)

\section{Alat Musik Pengiring}

Instrumen pengiring pada kesenian madihin adalah alat musik sejenis rebana yang disebut tarbang, alat musik tradisional ini berdiameter sekitar $30 \mathrm{~cm}$ dengan panjang $15 \mathrm{~cm}$. Fungsi alat musik ini sebagai pengiring dan ritmis dalam melagukan dan membawakan kesenian 
madihin ini. Iringan ini bersifat ritmis atau bukan berupa rangkaian melodi, sehingga yang menjadi melodi adalah lantuanan vokal yang diucapkan oleh pamadihinan. Sehingga harmonisasi yang dihadirkan adalah ketika keserasian diantara keduanya (lagu dan tarbang) menyatu dan berpadu dalam satu keindahan. Berikut merupakan contoh salah satu alat musik pengiring kesenian madihin (tarbang).

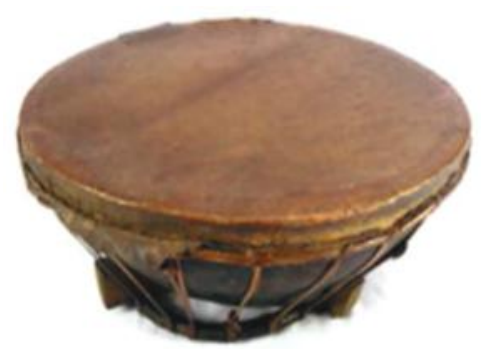

Gambar 3. Alat Musik Tarbang (Dokumentasi : M. Budi Zakia Sani, 2017)

\section{Struktur Penyajian Kesenian Madihin}

\section{a. Mambuka Alam}

Mambuka alam adalah nomenklatur yang digunakan untuk memberi nama pada tahap atau struktur yang paling awal dilakukan dalam sebuah pertunjukan kesenian madihin. Mambuka merupakan kata yang berawal dari bahasa lokal Banjar yang berarti membuka, sedangkan alam disimbolkan sebagai jalan atau permulaan tanda dimulainya sebuah pertunjukan. Sehingga mambuka alam adalah kegiatan atau proses mengawali bermulanya sebuah pertunjukan kesenian madihin.

Pada bagian mambuka alam ini ditandai dengan bunyi gebrakan awal alat musik pengiring pada madihin yaitu tarbang (sejenis rebana besar). Pola pukulan atau ritmis pada bagian mambuka alam ini biasanya bersifat rampak dan sekaligus lalu lintas bagi sebuah perjalanan pertunjukan kesenian madihin hingga akhir pertunjukannya.

\section{b. Mahadiyan (Hadiyan)}

Setelah dibuka dengan tarbang (mambuka alam) maka kemudian dilagukan sebuah alunan khas yang disebut dengan hadiyan. Hadiyan merupan sampiran pantun yang diambil dari isi atau inti yang akan disampaikan dalam pertunjukan kesenian madihin. Hadiyan terdiri dari dua baris sampiran pantun yang dilagukan secara khas dan unik oleh setiap pemadihinan. Hadiyan biasanya sesuai dengan kemampuan dan interpretasi seorang pamadihinan berdasarkan apa yang dimiliki oleh seorang pamadihinan tersebut. Berikut adalah contoh hadiyan yang secara umum dibawakan dalam pergelaran kesenian madihin.

$$
\begin{aligned}
& \text { Ilahi ...............iiiiii..........iiiii.iiiiii...... } \\
& \text { iiiii } \\
& \text { Lah jangan,jangan diputik..iiii....iiii....lah } \\
& \text { kambang sapatu, } 2 x \\
& \text { Ilahi.....,kambang malati....iiii...iiiii...... } \\
& \text { layu ditaman } 2 x
\end{aligned}
$$

Hadiyan umumnya dibuat oleh seorang pamadihinan bisa melalui pola spontanitas dan dengan pola konseptual. Pola spontanitas adalah bentuk hadiyan yang secara refleks merespon tematis sebuah permintaan pertunjukan.

\section{c. Mamasang Tabi Awal}

Mamasang tabi awal adalah membawakan syair-syair atau pantun yang isinnya menghormati penonton, memberikan pengantar, ucapan terima kasih, dan memohon maaf jika terdapat kekeliruan atau kesalahan dalam pergelaran. Berikut merupakan dua contoh fragmen syair dalam mamasang tabi awal.

Mamasang tabi awal biasanya dilakukan oleh seorang pamadihinan sebagai simbol selamat datang atau selamat menyaksikan kepada segenap penonton yang berada dalam pertunjukan. Simbol selamat datang ini selalu mengucapkan salam sebagai awal kata yang menyapa penonton untuk menghubungkan interaksi diantara pamadihinan dengan penontonya tersebut. Dalam teks mamasang tabi awal ini biasanya pamadihinan selalu memberi variasi rima bunyi akhir setiap tabi ini, dalam setiap tempat dan setting pertunjukan yang berbeda agar tidak terkesan monoton.

\section{d. Mamacah Bunga atau Kakambangan Mamacah bunga atau kakambangan adalah bagian yang posisinya berada menjelang}


memasuki ke bagian isi syair dalam pertunjuakan kesenian madihin. Mamacah bunga atau kakambangan adalah melanjutkan isi dari sampiran pantun yang dilagukan pada hadiyan . Isi dalam mamacah bunga ini sekaligus merupakan inti dari isi secara keseluruhan yang tercantum sepanjang pertunjukan madihin.

\section{e. Manguran atau Menyampaikan Isi}

Manguran atau menyampaikan isi adalah bagian inti dari seluruh struktur penyajian kesenian madihin secara menyeluruh. Manguran adalah memaparkan isi atau materi yang ingin disampaikan oleh pamadihinan dengan bermaksud memberikan kabar semacam seperti koran atau atau informasi mengenai suatu kejadian atau peristiwa. Isi dari naskah kesenian madihin ini bersifat fleksibel. Materi isi madihin mampu berperan sebagai media penyampaian pesan utama dalam misi pertunjukan madihin sebagai sebuah seni pertunjukan.

\section{f. Mamasang Tabi Akhir}

Mamasang tabi akhir adalah memberikan permintaan maaf oleh seorang pamadihinan kepada segenap penonton jika di dalam seluruh rangkaian pertunjukan terdapat suatu kesalahan atau hal yang kurang berkenan bagi seluruh penonton. Bagian ini adalah sebelum masuk pada akhir sebuah pertunjukan kesenian madihin, karena selama pertunjukan berlangsung mungkin kata-kata atau syair yang dibawakan oleh pamadihinan ada yang meyinggung perasaan penontonnya. Maka disinilah fungsi dari mamasang tabi akhir ini sebagai media komunikatif tidak langsung antara si pamadihinan dengan penontonnya.

\section{g. Mamantun atau Bapantun}

Mamantun atau bapantun adalah menyampaikan pantun sebagai tanda pertunjukan kesenian madihin akan segera berakhir. Bentuk pantun yang disampaikan biasanya berupa kesan yang baik agar setiap penonton selalu teringat dan terkesan dengan penampilan yang dibawakan oleh seorang pamadihinan. Jumlah pantun yang dibawakan biasanya tergantung pada pamadihinan, bisa satu pantun atau lebih tergantung situasi yang terjadi saat di panggung. Berikut contoh pantun yang umumnya dibawakan pada kesenian madihin.

Kalau ada umpama jarung nang patah (kalau ada jarum yangg patah)

Jangan disimpan di dalam pati (jangan disimpan di dalam peti)

Kalau ada kata ulun nang salah (kalau ada kata saya yang salah)

Jangan disimpan di dalam hati (jangan disimpan di dalam hati)

\section{h. Manutup Bulik}

Manutup bulik adalah tahapan terakhir dalam struktur penyajian kesenian madihin. Pada bagian ini adalah memberikan informasi kepada penonton bahwa pertunjukan madihin akan segera selesai dan berakhir. Pada tahap ini kata yang diucapkan sama dengan hadiyan yaitu kata Ilahi, sebagai tanda akhir pertunjukan kesenian madihin.

\section{Fungsi Kesenian Madihin}

Untuk mendukung penelitian ini juga digunakan teori R. M Soedarsono (2001) untuk menemukan fungsi pertunjukan yang ada di dalam kesenian madihin. Menurut R. M Soedarsono dalam mengkaji sebuah seni pertunjukan diklasifikasikan dalam fungsi primer dan fungsi sekunder, yaitu : (1) Sebagai sarana ritual; (2) Sebagai sarana hiburan pribadi; (3) Sebagai sarana presentasi estetis, sedangkan fungsi sekunder terdiri dari : (1) Sebagai sarana pengikat solidaritas masyarakat; (2) Sebagai sarana pembangkit rasa solidaritas bangsa; (3) Sebagai media komunikasi; (4) Sebagai media propaganda agama; (5) Sebagai media propaganda politik; (6) Sebagai media propaganda pemerintah; (7) Sebagai media meditasi; (8) Sebagai sarana terapi; (9) Sebagai perangsang produktivitas (Soedarsono, 2001: 170-171). Tidak semua fungsi teori tersebut di atas berkaitan dengan objek penelitian. Fungsi yang relevan saja yang akan diambil untuk mengetahui fungsi pertunjukan kesenian madihin setelah ditinjau dari teori fungsi pertunjukan Soedarsono (2001). Berikut adalah fungsi pertunjukan yang terdapat pada kesenian madihin menurut teori Soedarsono (2001). 


\section{a. Sebagai Sarana Ritual}

Fungsi kesenian madihin sebagai sarana ritual dapat dilihat pada saat pembukaan bagian hadiyan. Kata Ilahi merupakan komunikasi vertikal yang dilakukan oleh seorang pamadihinan dengan Sang Pencipta sebagai ungkapan rasa syukur dan melebur dirinya ke dalam imaji yang bersifat ilahiyah. Dalam kesenian madihin juga mengenal istilah pulung madihin atau maaruhi madihin untuk mendapatkan mandat dari Datu madihin mengenai profesinya sebagai seorang pamadihinan apakah direstui atau tidak. Namun, dalam realitasnya saat ini pulung ini sudah tidak terlihat lagi dilakukan oleh para seniman madihin yang ada di Banjarmasin.

\section{b. Sebagai Sarana Presentasi Estetis}

Kesenian madihin adalah sebuah karya seni yang memiliki nilai estetis yang tinggi. Kesenian ini telah hampir beratus-ratus tahun mampu eksis dan bertahan di kehidupan kebudayaan masyarakat Banjar yang majemuk. Bagi seorang seniman madihin, kesenian ini adalah sebuah sarana atau media bagi dirinya untuk mempresentasikan nilai-nilai keindahan yang ingin disampaikan dan dikomunikasikan dengan penontonnya. Penghadiran wujud estetis ini adalah sebuah legitimasi bahwa seorang pamadihinan merupakan kreator yang handal dalam pertunjukan yang ditampilkannya.

\section{c. Sebagai Pengikat Solidaritas Masyarakat}

Kesenian madihin merupakan hasil dari produk kebudayaan masyarakat Banjar pada masa silam. Kesenian madihin mencerminkan jati diri dan identitas masyarakat Banjar di dalamnya. Wujud Kesenian ini adalah upaya nyata dalam menjaga keterhubungan antara masyarakat dengan kesenian madihin itu sendiri. Karena kesenian madihin merupakan milik bersama masyarakat Banjar secara luas, maka secara tidak langsung kesenian madihin telah menjadi pengikat solidaritas masyarakat Banjar di kota Banjarmasin. Solidaritas masyarakat yang terjaga dengan baik akan berpengaruh positif pula pada keberlangsungan dan eksistens kesenian madihin di masa depan.

\section{d. Sebagai Pengikat Solidaritas Bangsa}

Kesenian madihin adalah identitas yang dapat mewakili identitas masyarakat Banjar pada tatanan kesenian di Nusantara. Kesenian madihin sebagai sebuah teks seni tentu memiliki jalinan koneksi budaya dengan kebudayaan lain di luar budayanya sendiri. Dalam hal ini, jika kesenian madihin sudah ditampilkan pada masyarakat bukan pemiliknya, maka secara nyata madihin telah menjalin sebuah komunikasi budaya dengan budaya lain. Dengan demikian kesenian madihin telah menjadi perekat untuk menyatukan dan mengikat keragaman budaya Nusantara yang di jalin dalam satu kesatuan budaya Indonesia.

\section{e. Sebagai Media Komunikasi}

Narasi menjadi kekuatan tersendiri bagi kesenian madihin dalam pertujukannya. Dengan narasi yang apik penonton akan mampu menghayati pertunjukan kesenian ini. Pada hakikatnya madihin sebagai wujud seni ingin menyampaikan sesuatu kepada setiap orang yang ada dihadapannya. Dalam hal ini informasi disalurkan melalui narasi yang disebut dengan jalinan komunikasi, komunikasi yang terjadi diantara pamadihinan dengan penontonnya. Madihin mampu berperan sebagai media komunikasi baik madihin dengan penontonnya atau madihin dengan konteks lain yang lebih luas di luar dirinya sendiri.

\section{Nilai-Nilai dalam Kesenian Madihin}

Hierarki nilai ini bersifat absolut dan mutlak untuk mengetahui kandungan nilai yang ada pada kesenian madihin. Hierarki nilai terdiri dari empat tingkatan nilai, yaitu (Frondizi, 2011:129): Pertama, tingkatan nilai yang paling tertinggi yaitu nilai-nilai kerohanian, nilai ini hanya akan tampak pada suatu objek yang absolut dan manusia. Kedua, tingkatan nilai yang kedua adalah nilai-nilai spiritualitas yang bersifat tidak tergantung pada keseluruhan keadaan lingkungan badaniah dan alam sekitar. Di dalam nilai-nilai spiritualitas terdapat tiga jenis pokok nilai meliputi: a. nilai estetis (nilai yang berkaitan dengan keindahan dan kejelekan); b. nilai benar dan salah atau 
adil dan tidak adil (sebagai dasar utama dalam pemilaian tatanam hukum objektif); c. nilai dari pengetahuan murni. Ketiga, tingkatan nilai yang ketiga yaitu nilai kehidupan, meliputi kesehatan, vitalitas, penyakit (menyangkut perasaan yang halus atau luhur). Keempat, tingkatan nilai terendah ini yaitu nilai kesenangan, tingkatan ini berkaitan dengan perasaan yang diterima oleh indera tubuh atau bersifat inderawi (senang dan tidak senang, sakit atau pedih).

Sepadan dengan kategori nilai dalam hierakri nilai Max Scheler tersebut, Sunarto (2016:87) menyebutkan bahwa dalam aksiologi seni Nusantara terjadi jalinan yang erat antara keempat jenis nilai, yaitu kekudusan, kebenaran, keindahan, dan kebaikan. Hal ini menegaskan bahwa kesenian madihin sebagai salah satu seni Nusantara adalah merupakan sumber etika dan estetika bagi masyarakat pemilik kesenian tersebut, yang mana nilai yang terkandung di dalam kesenian madihin itu memiliki jalinan yang saling terkait antara satu dengan yang lainnya.

Widodo (2008:167) menyebutkan bahwa ada dua kategori pemerolehan nilai. Ada nilai yang diperoleh atau lahir disebabkan realiras konkret yang difahami dengan fikiran. Ada pula nilai yang diperoleh atas realitas spiritual, yaitu kalbu. Artinya keberadaan nilai yang ada di dalam kesenian madihin dapat diungkapkan dengan fikiran atau logika berdasarkan realitas yang terlihat secara langsung oleh subjek, dan juga dapat diperoleh dari kalbu atau perasaan yang bersifat intuitif berdasarkan kemampuan dan pemahaman spiritual yang ada pada objek material yaitu kesenian madihin di Banjarmasin.

Berdasarkan atas analisis dalam hasil penelitian dapat diuraikan empat tingkatan hierarki nilai yang terkandung di dalam kesenian madihin sebagai berikut.

\section{a. Nilai-nilai Kekudusan \\ 1) Nilai religiusitas}

Religi adalah sebuah cara manusia dalam rangka untuk menentukan jalan bagi kembalinya kepada Sang Maha Pencipta. Sesuatu yang dipercayai dan bertitik pada hati yang paling dalam seorang manusia, menegaskan bahwa tiada hal pun di dunia ini yang ada dengan sendirinya melainkan dari kehendak Yang Maha Kuasa. Nilai religiusitas dalam kesenian madihin dapat dilihat dari bentuk hadiyan dalam struktur penyajian kesenian madihin. Contohnya sebagai berikut.

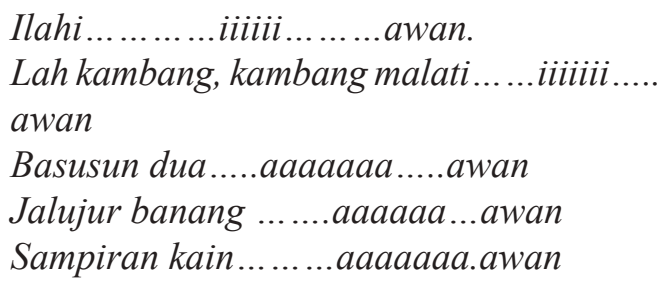

Bagian diatas merupakan salah satu bentuk dari struktur kesenian madihin yang disebut dengan hadiyan. Dalam hadiyan secara jelas disebutkan kata Illahi, yang mana kata ini mengandung makna melebur diri atau menyerahkan segala urusan yang dilakukan oleh pamadihinan kepada Tuhan Yang Maha Kuasa. Kata Illahi memiliki makna yang sangat dalam, mampu menjembatani fikiran antara imajinasi dengan kekuatan kepercayaan batin pamadihinan kepada Sang Pencipta. Oleh karena itu hadiyan merupakan bagian yang penting dalam pertunjukan kesenian madihin, karena disitulah letak inti dari hidup yang diwujudkan dalam melakoni sebuah seni sebagai jalan atau sarana menuju kepada hidup yang ilahiyah.

Nilai religiusitas merupakan hierarki nilai yang paling tinggi yang ditemukan dalam kesenian madihin. Nilai religiusitas yang termasuk dalam nilai kekudusan ini merupakan implikasi dari hubungan langsung antar seorang manusia dengan Tuhannya. Nilai ini memiliki tingkatan hierarki yang paling tinggi, karena urusan manusia dengan Tuhan merupakan hubungan gaib yang hanya dapat dirasakan oleh individu yang tidak akan sama takarannya dengan individu lainnya. Sehingga, nilai religiusitas dalam kesenian madihin layak untuk dijadikan sebagai tingkatan tertinggi dalam susunan gugus nilai yang ada dalam kesenian madihin tersebut. 


\section{2) Nilai magis}

Kesenian madihin mengenal istilah pulung madihin. Pulung adalah kekuatan supranatural yang berasal dari alam gaib yang diberikan oleh datu madihin. Konon, berkat pulung seseorang pamadihinan dapat mengembangkan kemampuan bakat dan intelektualitasnya hingga ke tingkat yang kreatif atau mumpuni (Ganie, 2016:22). Pulung dalam konteks ini yang menyebabkan tidak semua orang akan mampu memainkan kesenian madihin dengan terampil dan mahir, karena pulung merupakan bentuk transaksi yang bersifat abstrak antara juriat pemain madihin dengan nenek moyangnya.

Kesenian madihin juga mengenal istilah datu madihin. Datu madihin adalah seorang tokoh mistis yang bersemayam di Alam Banjuran Purwa Sari, alam pantheon yang tidak kasat mata, tempat tinggal para dewa kesenian rakyat. Datu madihin diyakini sebagai orang pertama yang secara geneologis menjadi cikal bakal penggubah syair madihin di kalangan etnis banjar (Ganie, 2016:22). Kemudian juga dalam kesenian madihin diadakan Aruh madihin yang mana fungsinya untuk mengundang datu madihin sebagai tanda silaturahmi untukk direstui atau tidaknya seorang pemain madihin untuk terus berkarir atau tidak dalam dunia pemadihinan. Aruh madihin biasanya diadakan setahun sekali dengan memberikan beberapa sesaji berupa nasi ketan, kelapa, telur ayam kampung, dan minyak baboreh secukupnya. Dalam aruh madihin biasanya seorang pamadihinan akan mengalami kesurupan (trance) yang menadakan bahwa mandat datu madihin telah diberikan kepadanya sebagai tanda untuk meneruskan profesinya sebagai seorang pamadihinan yang profesional.

Kedudukan mitos sendiri dalam tingkatan hierarkinya lebih rendah posisinya daripada nilai religiusitas, sehingga hal yang bersifat magis akan lebih rendah kedudukannya karena hanya berurusan dengan hal gaib yang masih menyangkut antara sesama makhluk ciptanaa Tuhan, misalnya antara manusia dengan jin.

\section{b. Nilai-nilai Spirit atau Rohani \\ 1) Nilai Moralitas \\ a) Nilai Tanggung Jawab}

Nilai tanggung jawab merupakan nilai tertinggi yang ditemukan dalam tatanan nilai moralitas kesenian madihin. Nilai tanggung jawab merupakan urusan yang melibatkan antara kewajiban dan tujuan tindakan perilaku manusia. Nilai tanggung jawab dapat dilihat ketika seorang pamadihinan mampu menyelesaikan pertunjukan madihin dari awal sampai akhir dengan baik. Tanggung jawab terhadap penonton juga merupakan bagian yang penting bagi seorang pamadihinan, karena tanpa adanya penonton pertunjukan madihin tidak akan menjadi satu kesatuan yang lengkap. Pertunjukan secara keseluruhan adalah hak mutlak penonton, sehingga seorang pamadihinan harus mampu menunaikan kewajibannya atas penampilan yang baik dan sesuai dengan harapan penonton.

Orang Banjar mempunyai sebuah istilah yang relevan dengan nilai tanggung jawab yang terdapat pada kesenian madihin. Istilah tersebut adalah gawi manuntung, yang serign disebut dalam keseharian aktifitas kerja masyarakat secara umum. Gawi manuntung memiliki makna jika melakukan suatu pekerjaan hendaknya dilakukan sampai tuntas dan selesai. Hal ini sama dengan pementasan madihin, karena secara struktur madihin memiliki urutan yang harus dilakukan. Maka dalam sebuah pementasan madihin harus ada sikap dan rasa tanggung jawab untuk menyelesaikan pertunjukan sampai akhir. Spirit gawi manuntung itu adalah sifat yang dimiliki oleh orang banjar yang tergambar dalam serat kesenian madihin.

\section{b) Nilai Kedisiplinan}

Nilai kedisiplinan dapat terlihat ketika seorang pamadihinan sedang berada diatas panggung. Ketika sedang mementaskan madihin diwajibkan untuk disiplin dan mampu mentaati semua struktur dan prosedur yang ada dalam urutan penyajian pertunjukan madihin. Awalan dilakukan dengan pembukaan memukul tarbang lalu kemudian diiringi dengan hadiyan yang sangat khas, dilanjutkan dengan tabi 
dan kemudian mamacah bunga, kemudian penyampaian isi, dan penutup biasanya disuguhkan sebuah pantun. Dengan menaati tata aturan yang sudah baku dalam struktur permaianan madihin ini sudah menggambarkan nilai kedisiplinan yang tergambar dalam kesenian madihin.

Nilai kedisiplinan juga bisa dilihat ketika memainkan atau menyanyikan syair lagu sesuai dengan iringan musiknya dalam satu kesatuan yang tepat dan serasi. Dalam mementaskan sebuah pertunjukan madihin, seorang pamadihinan dituntut harus cerdas dalam menyatukan unsur nyanyi, musik, dan merangkai kata. Dengan kata lain harus ada keserasian antara bertutur, bermusik, dan berfikir guna merangkai kesatuan pertunjukan.

Hal mengenai kedisiplinan akan menarik jika kita kaitkan dengan sebuah peribahasa Banjar yang berbunyi nang kaya upuk mamadahi mayang. Makna daripada peribahasa tersebut diatas adalah bahwa seseorang telah memberitahu atau memerintahkan orang lain namun dirinya sendiripun tidak melakukan hal tersebut, atau tidak memberikan contoh yang baik kepada yang diperintahkan. Kebaikan yang dapat kita petik dari contoh peribahasa diatas adalah bahwa jika kita ingin mengajarkan suatu kedisiplinan kepada orang lain maka kita harus terlebih dahulu melakukan atau memberikan contoh supaya ditiru atau dilakukan berikutnya.

\section{c) Nilai Toleransi}

Nilai toleransi terlihat pada saat pamadihinan membiarkan penonton untuk memberikan tepuk tangan ketika syair yang sisampaikan mengandung unsur humor atau jenaka. Humor atau jenaka ini dibuat oleh pamadihinan untuk menyihir penonton agar bertepuk tangan dan melemparkan tawa yang lepas, sehingga pada saat momen ini pamadihinan wajib memberikan ruang kepada penonton untuk meluapakan rasa senangnya. Sehingga rasa toleransi antara pamadihinan dan penonton secara tidak sengaja sudah terjadi dalam kesenian madihin.

Orang banjar sangat menghargai akan adanya sikap toleransi dalam kehidupan seharihari. Jika kita lihat sebuah peribahasa banjar yang berbunyi hantu-hantu kuyang-kuyang, aku-aku urang-urang, maka akan dapat kita ambil sebuah penjelasan yang bermakna bahwa peribahasa diatas mengandung arti hidup adalah urusan masing-masing manusia yang memiliki hak tersendiri atas kewajibannya. Namun dalam artian yang lebih dalam peribahasa tersebut mengandung makna bahwa sebuah toleransi adalah sebuah tindakan yang berdasar atas norma yang berlaku dan dianut secara bersama oleh lingkungan tertentu. Sehingga hal tersebut merupakan gambaran yang dihadirkan oleh kesenian madihin sebagai kesenian yang mengandung nilai keluhuran (toleransi) kepada orang lain yang sesuai dengan prinsip hidup orang Banjar.

\section{d) Nilai Cinta Tanah Air}

Nilai Cinta Tanah Air adalah sebuah sikap yang mencerminkan rasa nasionalisme yang kuat pada individu seseorang. Rasa memiliki dan mencintai terhadap nusa dan bangsa adalah wujud nyata dari rasa cinta tanah air tersebut. Dalam kehidupan seahri-hari rasa cinta tanah air ini perlu selalu dilatih dan dipupuk pada generasi muda khususnya, karena ini merupakan sebuah pronsip dasar mengenai konsep bela negara nantinya. Oleh karena itu rasa cinta tanah air perlu dikembangkan baik melalui proses pendidikan dan aktifitas lainnya.

Cinta tanah air merupakan terusan dari rasa mencintai kedaerahan. Dalam hal ini kita kaitkan dengan kesenian madihin sebagai salah satu produk kesenian lokal nusantara yang berasal dari Kalimantan Selatan. Sebagai salah satu cara untuk menumbuhkan dan membibit nilai cinta tanah. Oleh karena itu sangat penting untuk mengapresiasi kesenian daerah sendiri maupun kesenian daerah yang berasal dari daerah lain, karena dengan makna apresiasi maka akan tumbuh rasa saling menghargai yang akan menciptakan rasa dan nilai cinta tanah air.

\section{e) Nilai Kerja Keras}

Nilai kerja bisa dilihat dari upaya seorang pamadihinan baik dalam proses belajar madihin dan belajar memainkan alat musik iringannya tarbang. Dalam proses belajar kesenian madihin 
memerlukan kerja keras, karena kesenian ini merupakan salah satu kesenian yang tidak mudah untuk dipelajari secara cepat dan sekilas. Belajar kesenian madihin memerlukan kesabaran dan kerja keras yang tinggi. Selain itu juga dalam mengiringi atau memainkan tarbang madihin sebagi musik pengiring juga adalah sebuah kerja keras yang sangat diperlukan bagi seorang pamadihinan yang memang benarbenar ingin belajar dan mahir dalam memainkan kesenian madihin.

Nilai kerja keras ini berbanding lurus dengan prinsip hidup urang banjar yaitu haram manyarah, waja sampai kaputing. Hal tersebut mencerminkan bahwa urang Banjar memiliki semangat juang yang besar dalam hidupnya dalam mencapai suatu tujuan atau kehendak.. Peribahasa tersebut pernah diucapakan seorang Pahlawan Nasional Pangeran Antasari yang berasal dari Kalimantan Selatan pada saat memimpin perang Banjar menghadapi para penjajah Belanda sebelum era kemerdekaan, yang mana ucapan beliau tersebut dijadikan masyarakat banjar sebagai peribahasa yang sangat prinsipal dalam menjalani hidup, yaitu nilai kerja keras yang terkandung di dalamnya.

Sumasno Hadi (2017: 35) menyatakan bahwa ketika orang Banjar dilihat dalam perspektif falsafahnya yang punya prinsip kerja keras sebagai salah satu prinsip moralnya, sebenarnya hal itu adalah konsekuensi logis dari aspek teleologis (tujuan), yang secara umum didambakan oleh setiap manusia. Hal ini dapat dikaitkan dengan nilai kerja keras yang terdapat di dalam kesenian madihin. Nilai kerja keras tersebut sendiri adalah sesuatu yang sebenarnya sesuai dengan falsafah hidup orang Banjar mengenai tujuan dalam hidup yang harus dilalui dan dilakukan dengan kerja keras. Nilai kerja keras ini menggambarkan tentang kegigihan semangat hidup dan semangat juang orang Banjar yang tergambarkan melalui sebuah kesenian yaitu madihin.

\section{f) Nilai Kreatif}

Madihin kocak yang dibuat oleh John Tralala pada era awal tahun 90an merupakan penggubahan yang sangat berpengarug pada pola permaianan madihin saat ini. Kreatifitas John Tralala pada saat itu sudah mengajarkan kita bahwa sebuah hasil pemikiran baru telah mampu menjawab tantangan pada zamannya. Seorang seniman yang kreatif akan menghasilkan karya yag kreatif juga.

Kreatifitas dalam madihin juga sangat bisa dilihat dari improvisasi yang dilakukan oleh seorang pamadihinan dalam melantunkan syair spontan yang hadir tanpa dirancang dan direncanakan oleh seorang pamadihinan. Spontanitas inilah yang terkadang sangat sulit dimiliki oleh seorang pamadihinan, karena kemampuan ini tidak bisa didapatkan secara mudah, memerlukan waktu yang cukup lama dalam berlatih madihin untuk mampu atau dikategorikan mahir dalam memainkan kesenian madihin tersebut.

Secara tidak langsung dapat kita lihat bahwa dalam salah satu inti kesenian madihin sangat kental sifatnya berkaitan dengan unsur kreatifitas, kemampuan lagu, iringan musik, dan penuturan secara lisan mengajarkan kita bagaimana nilai kreatifitas itu terkandung secara objektif di dalam kesenian madihin. Nilai kreatifitas yang tampak pada setiap kesenian madihin mampu menginspirasi siapa saja yang menyaksikan pertunjukan madihin. Dalam tatanan ini madihin telah mampu memberikan hal yang bersifat positif bagi siapa saja yang telah atau pernah menyaksikan kesenian tersebut.

\section{g) Nilai Bersahabat/Komunikatif}

Nilai Komunikatif salah satunya dapat dilihat ketika seorang pemain madihin sedang menyebutkan nama salah seorang penonton atau melibatkannya dalam materi madihin yang disampaikan. Biasanya itu dilakukan oleh pamadihinan pada awal pertunjukan, yang mana bagian itu merupakan salah satu cara untuk memberikan hormat dan menarik simpati penonton yang hadir dalam pertunjukan madihin. Madihin sejatinya dalah sebuah kegiatan komunikasi antara pamadihinan dengan penontonnya, atau pada konteks yang lebih luas yaitu antara pamadihinan dengan lingkungan sekitar yang sedang dihadapinya. 
Alo Liliweri (2013: 5) mengatakan bahwa esensi komunikasi terletak pada proses, yaitu suatu aktifitas yang melayani hubungan antar pengirim dan penrima pesan melampaui ruang dan waktu. Keterlibatan penonton dalam suatu pertunjukan akan memberikan dampak yang baik bagi pamadihinan, karena pamadihinan menyampaikan pesan kepada yang merupakan teks untuk berkomunikasi dengan penontonnya. Sehingga kondisi ideal yang diinginkan dalam pertunjukan akan tercapai, penonton yang merasa dirinya terlibat dalam suatu pertunjukan akan memiliki rasa saimpatik yang lebih mengenai apresiasinya terhadap suatu kesenian.

Mengkomunikasikan narasi madihin kepada penonton yang sedang menyaksikan sebuah pertunjukan kesenian madihin, misalnya dengan menyebutkan nama tadi akan membuat gembira atau tersanjung bagi penonton tersebut. Hal ini meberitahukan kita bahwa kesenian madihin sangat erat sifatnya dengan nilai komunikatif

\section{2) Nilai Estetis}

Kesenian madihn sangat erat berkaiatan dengan yang bernama nilai estetis atau nilai keindahan, yang terungkap dan terdapat di dalamnya seperti: a. syair, b. lagu, c. iringan musik, d. Kostum atau tata busana. Adams (1996:17) mengatakan bahwa a formalist analysis of a work of art would cinsider primarily the aesthetic effects created by the component part of design. Hal demikian berarti bahwa sebuah analsis formal dari pekerjaan dalam seni utamanya akan mempertimbangkan efek estetika yang dihasilkan dari bentuk sebuah desain. Dalam kaitannya dengan kesenian madihin adalah bentuk atau desain kerangka secara utuh merupakan hasil dari efek estetika yang dalam penciptaan kesenian tersebut pada awal mulanya. Sehingga kesenian madihin memiliki nilai estetika di dalamnya adalah merupakan hasil dari kenyataan realitasnya sendiri.

\section{a) Syair}

Syair dalam kesenian madihin meliputi seluruh kata-kata yang diucapkan dari awal sampai berakhirnya sebuah pertunjukan madihin. Syair adalah ungkapan yang secara nyata dapat menyampaikan pesan dan makna yang terkandung di dalam kesenian madihin. Deni Junaedi (2016: 234) menyebutkan bahwa masterly adalah nilai estetis yang tercermin pada suatu objek yang mempresentasikan penguasaan atau keterampilan seorang kreator.

Dalam hal ini kaitannya dengan kesenian madihin menunjukkan bahwa keterampilan seorang pamadihinan dalam membuat syair madihin mempresentasikan dan mencerminkan nilai estetis yang terkandung di dalam kesenian madihin sendiri sehingga syair memiliki peran yang sangat penting dalam sebuah pertunjukan madihin, sehingga kemampuan dalam membuat naskah atau syair madihin yang berkualitas adalah sebuah kecerdasan seorang pamadihinan yang memiliki nilai keindahan atau estetika yang sangat kental dan khas. Nasihat yang dipadukan dengan nuansa humor akan menjadi sajian yang sangat menarik bagi penikmat kesenian madihin.

\section{b) Lagu}

Kesenian madihin memiliki keindahan pada bentuk melodi lagunya, lagu madihin tersebut memiliki 2 jenis lagu utama. Lagu pertama disebut dengan lagu hadiyan, dan lagu yang kedua disebut dengan lagu jalan. Lagu hadiyan merupan bagian awal dari bermulanya pertunjukan kesenian madihin, sedangkan lagu jalan merupakan lagu yang secara berulang-ulang dinyanyikan ketika sudah memasuki bagian isi dan selanjutnya. Lagu jalan memiliki 4 kalimat bunyi dasar yang terdapat dalam lagu madihin. Empat kalimat bunyi dasar tersebut akan secara berulang-ulang dilagukan menyesuaikan dengan syair yang akan dibawakan dalam pertunjukan kesenian madihin. Theories of listening find paradigmatic support in aestetjic theory, which in turn is based on the relation between the creators and the perceiver of the art product (Gates, 1991:5). Kutipan di atas mengandung arti bahwa teori mendengarkan menemukan pandangan yang mendukung teori estetika, yang menjadi satu dalam hubungan antara kreator dan penikmat 
produk seni. Alunan lagu dalam kesenian madihin adalah bentuk dari perpaduan syair dan iringan musiknya yang menghubungkan sebuah koneksi antara pamadihinan dengan penontonnya. Dalam hal ini kesenian sebagai produk seni telah menyampaikan nilai estetika kepada setiap penontonnya yang menyaksikan dan menikmati pertunjukan madihin .

Sedangkan pada bagian isi, alunan lagu yang dihasilkan berbentuk repetatif atau pengulangan yang juga terbilang unik. Kemampuan melagukan madihin sangat fleksibel dengan bentuk syair atau kata yang harus diucapkan, sehingga melagu akan selalu mengikuti bentuk dari kata yang diikutinya, sehingga bentuk yang seperti ini akan menimbulkan kesan menarik dan unik bagi penonton dalam kesenian madihin. Madihin yang berdurasi pendek dan madihin yang berdurasi lama tidak akan berpengaruh terhadap bentuk melagu yang dibawakan, artinya ketentuan untuk lagu dalam madihin memang sudah ada aturan dan tatanan yang seharusnya.

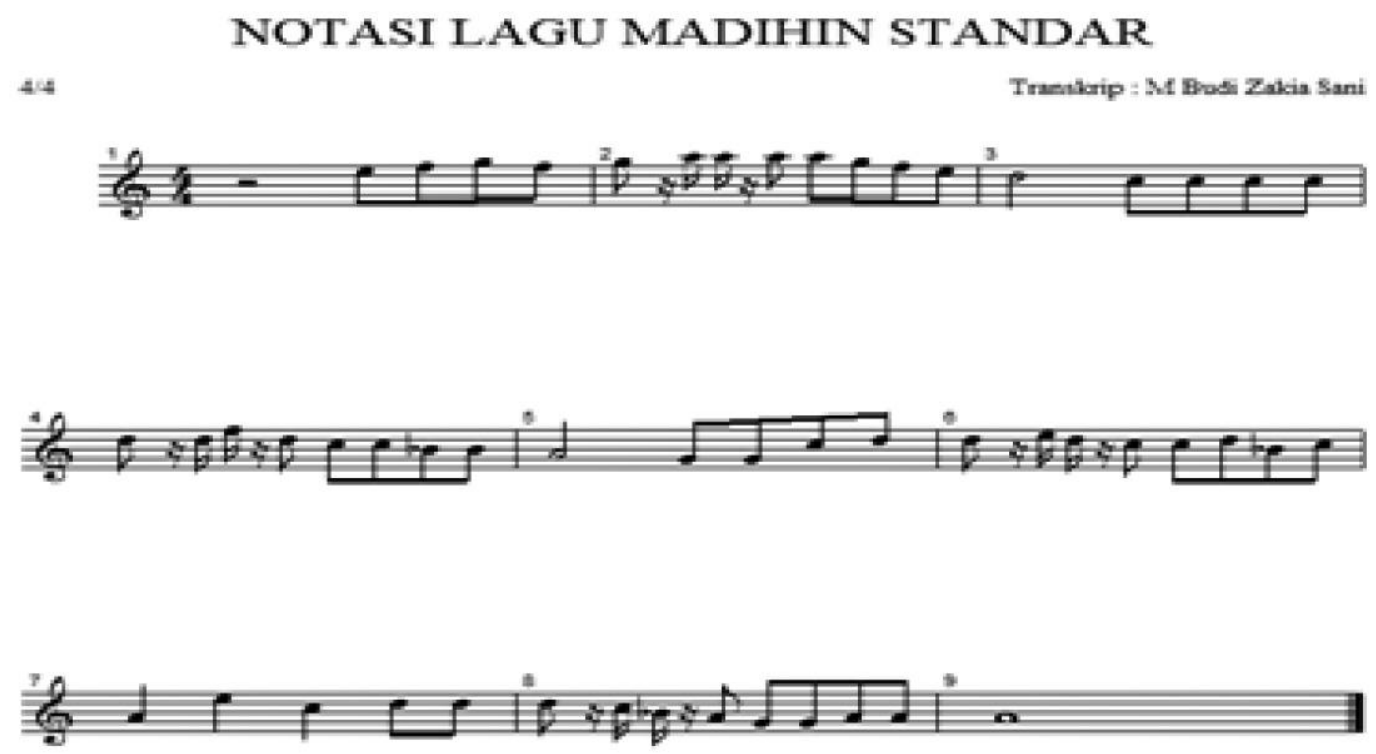

Gambar 4. Notasi Pada Lagu Standar Madihin

\section{c) Iringan musik}

Iringan musik dalam kesenian madihin menggunakan sebuah alat musik yang dinamakan dengan tarbang. Alat musik jenis perkusi ini mengiringi madihin secara ritmis yang bisa dibagi menjadi dua bentuk. Pertama adalah jenis pukulan pembuka (mambuka alam), dan yang kedua adalah jenis pukulan lagu standar, yang mana kedua jenis pukulan ini memiliki pola ritmis yang berbeda dan tidak sama.
Pola pertama, yaitu pukulan mambuka alam memiliki variasi yang lebih banyak, biasanya pukulan ini lebih kepada improvisasi seorang pamadihinan. Namun disini telah ditemukan bahwa pukulan mambuka alam yang standar atau yang umum digunakan oleh pamadihinan John Tralala adalah sebagai berikut yang sudah ditukis ke dalam notasi balok : 


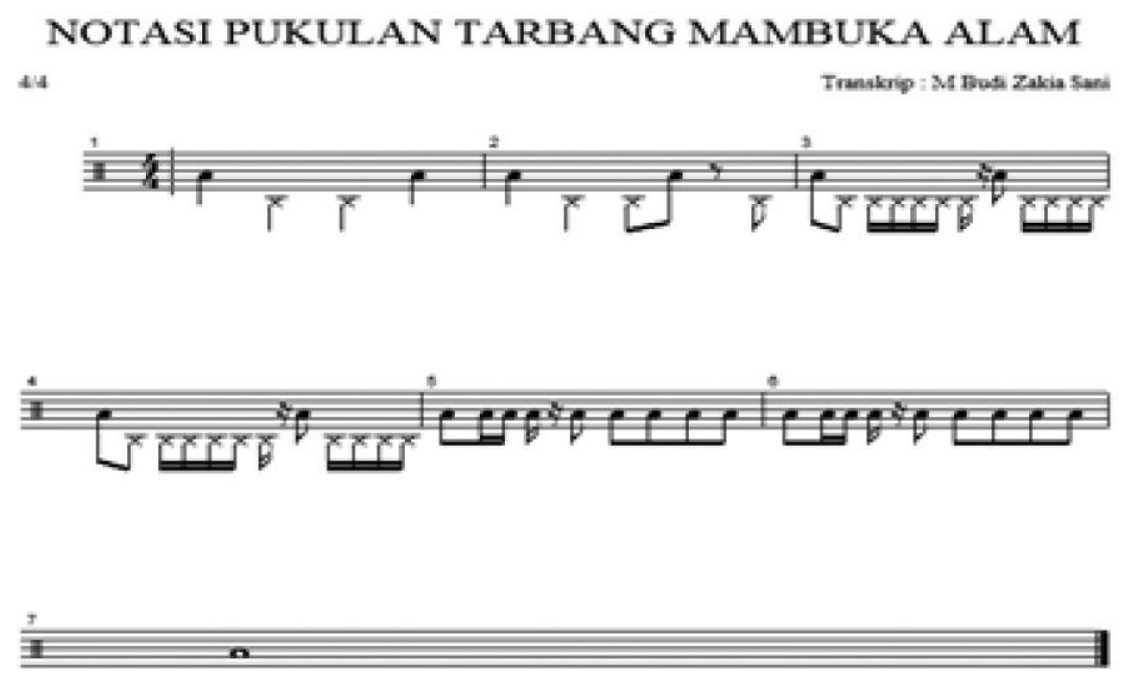

Gambar 5. Notasi Pukulan Tarbang Pembuka

Sedangkan pukulan isi atau manguran lebih bersifat repetatif dan stabil, dengan birama 4/4 dalam setiap ketukan iramanya. Dalam keahlian dan kemampuan mengiringi musik ini biasanya akan menentukan sejauh mana tingkat keserasian antara syair dan bunyi tarbang yang dipukul oleh seorang pamadihinan. Jika keahlian dalam memainkan tarbang ini masih terbilang kurang, maka yang akan terjadi adalah kurang sinkronnya antara vokal (lagu) syair denga iringan musik tarbang tersebut. Nilai keindahan yang dihasilkan akan menjadi kurang. Maka dari itu keserasian antara iringan musik dengan vokal (lagu) sangatlah diperlukan sehingga membuat penonton memberikan tepuk tangan dan terpukau atas suatu pertunjukan madihin. Berikut adalah pukulan isi atau manguran yang sudah dinotasikan ke dalam notasi balok dapat dilihat pada gambar 6 .

\section{3) Nilai Budaya}

Kesenian madihin sebagai identitas kebudayaan masyarakat Banjar jika dilihat dari kesejarahannya memang sudah ada sejak lahirnya identitas Banjar tersebut. Sejak zaman dulu sampai sekarang madihin adalah sebuah kesenian yang mencerminkan identitas dan jati diri orang Banjar. Kesenian madihin yang terus mengalami perkembangan dari satu zaman ke zaman berikutnya telah menjadi budaya bagi masyarakat Banjar. Kesenian madihin ini telah berabad-abad mampu bertahan hingga mampu eksis sampai saat ini adalah merupakan suatu ketahanan budaya yang memiliki makna tersendiri (nilai budaya). Nilai budaya yang terkandung dalam kesenian madihin dapat dirinci selaras dengan nilai-nilai yang terungkap di dalam kesenian madihin.

Kebanggan masyarakat Banjar akan kesenian madihin itu semakin bertambah karena sejak tahun 2014 lalu madihin sejak ditetapkannya madihin oleh UNESCO melalui Mentri Pendidikan dan Kebudayaan Indonesia sebagai salah satu Budaya Warisan Tak Benda milik Indonesia asal Kalimantan Selatan. Hal ini semakin menegaskan bahwa madihin sendiri telah diakui secara universal sebagai sebuah kebudayaan yang bersifat adiluhung dan endemik yang ada di Indonesia sebagai salah satu serat kebudayaan yang sangat kaya di Nusantara ini.

\section{Nilai-nilai Kehidupan atau Vitalitas 1) Nilai Kesejahteraan}

Nilai kesejahteraan dalam kesenian madihin adalah sejauh mana kesenian madihin tersebut dapat memberikan ketentraman ndan kemakmuran pada seniman madihin baik secara lahir maupun batin. Tentram itu adalah kondisi dimana secara batin seseorang telah mampu merdeka dan tidak mengalami kesukaran. Sedangkan makmur adalah kondisi 


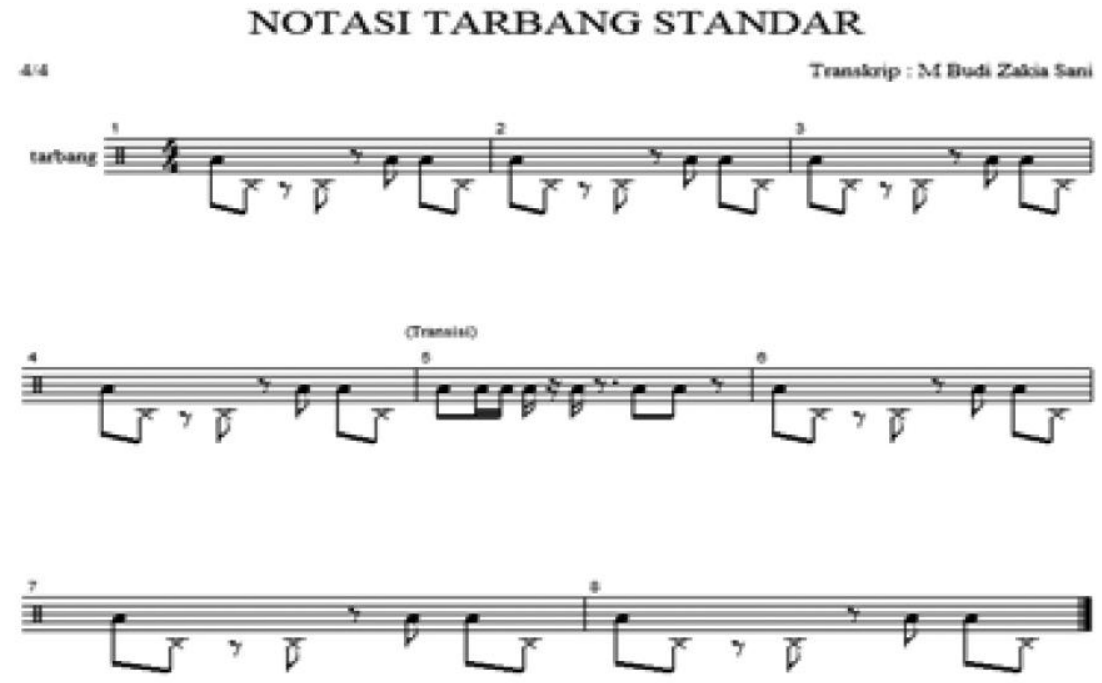

Gambar 6. Notasi Pukulan Standar Atau Isi/Maguran

dimana seseorang telah merdeka secara lahir dapat memenuhi segala kebutuahn yang bersifat mendasar maupun kebutuhan lainnya. Kesenian madihin sebagai kesenian tardisional ternyata mampu membuat ketentraman bagi seniman madihin itu sendiri maupun masyarakat Banjar secara luas. Nilai-nilai kesejahteraan tersebut tanpa disadari telah menjadi dasar bagi kehidupan masyarakat sehari-hari.

\section{Nilai-nilai Kesenangan \\ 1) Nilai Kepuasan}

Nilai kepuasaan adalah suatu gambaran perasaan lega, ungkapan kegembiraan, perasaan senang dan terpenuhinya suatu keinginan atau hasrat. Dalam kesenian madihin jika dikaitkan dengan unsur nilai kepuasan maka akan dapat terlihat dan terungkap dalam diri pamadihinan jika sudah mampu menyelesaikan tugasnya dengan baik. Selain juga mendapatkan kepuasan estetis, pamadihinan juga mampu menyalurkan hobinya yang membuat hal positif bagi pamadihinan tersebut.

Kepuasaan ini juga dapat terungkap dari yang meminta hajat atas madihin atau orang yang melakukan tanggapan terhadap madihin. Misalnya dalam hiburan perkawinan kesenian madihin yang telah ditampilkan akan memberikan rasa lega kepada yang punya hajat karena sesuatu yang diinginkan telah terpanuhi dan timbul rasa puas dan senang di dalam hatinya. Setiap tanggapan itu membuat sang penanggap akan selalu ingat dengan pamadihinan, karena kesan yang dihadirkan adalah rasa terima kasih atas perkenan seorang pamadihinan dalam menunaikan keinginan penanggap.

\section{2) Nilai Material}

Istilah material adalah sesuatu yang bersifat nampak atau berwujud. Unsur material yang berkaitan dengan kesenian madihin adalah sesuatu yang berhubungan dengan rasa senang. Kesenian madihin merupakan sumber yang dapat memberikan rasa senang kepada siapapun. Rasa senang itu dapat dirasakan jika seorang pamadihinan memainkan madihinnya, namun jika madihin itu tidak dimainkan maka tidak akan ada rasa senang itu. Rasa senang itu bisa muncul ketika terjadi interasksi antara pamadihinan dengan pamadihinan, maupun antara pamadihinan dengan penonton.

\section{3) Nilai Hiburan}

Hiburan adalah sesuatu yang berkaitan dengan kegiatan untuk melupakan kesedihan atau duka nestapa. Hiburan adalah suatu kebutuhan wajar yang diinginkan oleh setiap pribadi manusia. Lelahnya aktifitas membuat manusia memerlukan waktu untuk menghibur diri atau relaksasi. Kegiatan menghibur adalah memberikan rasa kesenangan pada diri sendiri 
atau pada orang lain. Hiburan merupakan sesuatu yang juga bersifat penting bagi manusia, apalagi dalam urusan seni, hiburan untuk menenangkan jiwa dan fikiran.

Kesenian madihin jika dikaitkan dengan nilai hiburan ini maka akan lebih besar pengaruhnya dibanding dengan nilai-nilai yang lain. Kesenian madihin adalah kesenian yang sangat digemari dikalangan masyarakat Banjar, sehingga madihin menjadi sebuah daya tarik yang tersendiri bagi masyarakat Banjar. Salah satunya adalah kondisi komunikatif yang dihadirkan pada saat kesenian madihin mampu membuat penonton merasa lebih terlibat dalam setiap pertunjukan madihin yang dihadirkan.

Berdasarkan penelitian dan analisis yang telah dilakukan terhadap nilai-nilai moralitas dalam kesenian madihin maka telah ditemukan beberapa nilai-nilai yang memiliki relevansi dengan nilai-nilai yang dijadikan acuan dalam pembentukan pendidikan karakter. Nilai-nilai moralitas yang memiliki relevansi tersebut antara lain adalah sebagai berikut.

\section{1) Nilai Religiusitas}

Nilai religiusitas yang terkandung di dalam kesenian madihin bisa dijadikan sebagai model atau sarana dalam pembentukan nilai pendidikan karakter pada proses pembelajaran formal, maupun nonformal dan informal. Nilai religiusitas dalam sebuah kesenian tradisional memiliki seperti kesenian madihin memiliki daya tarik tersendiri, karena sebuah kesenian akan memberikan pengaruh yang berbeda terhadap proses pembelajaran di dalamnya.

\section{2) Nilai Tanggung Jawab}

Nilai tanggung jawab merupakan salah satu dari nilai yang dicantumkan di dalam pendidikan karakter. Karakter bertanggung jawab adalah perbuatan yang berani mempertanggung jawabkan segala resiko dari aktifitas yang dilakukan. Bertanggung jawab atas sesuatu bukanlah perbuatan yang mudah, karena bertanggung jawab adalah bagaimana seseorang mampu mengelola keinginan dengan kenyataan yang dihadapi dalam setiap masalah yang didapatkan. Intisari dari nilai bertanggung jawab adalah menahan diri agar menaati aturan yang berlaku.

\section{3) Nilai Disiplin}

Nilai disiplin yang terkandung di dalam kesenian madihin merupakan salah satu alternatif atau cara lain untuk mengemban misi dari pendidikan karakter di Indonesia saat ini. Nilai disiplin di dalam sebuah kesenian tradisional khususnya merupakan model atau percontohan yang baik bagi proses sebuah pembelajaran. Pembelajaran yang bersifat pendidikan formal, informal, maupun nonformal. Sehingga nilai disiplin yang terkandung di dalam kesenian madihin bisa memberikan manfaat bagi pendidikan.

\section{4) Nilai Toleransi}

Nilai toleransi adalah sebuah nilai mengenai pentingnya menghargai keberadaan orang lain. Toleransi mengajarkan bagaimana caranya untuk menghormati dan memberi kesempatan kepada individu lain untuk melakukan aktifitasnya. Nilai toleransi yang terdapat dalam kesenian madihin adalah merupakan contoh bahwa kesenian berbasis kepada khasanah kekayaan lokalitas Nusantara yang bisa dijadikan sebagai sarana untuk mengajarkan nilai toleransi yang dimaksud oleh pendidikan karakter. Nilai toleransi yang terdapat di dalam kesenian madihin mampu menjadi contoh dalam memahami dan melaksanakan nilai toleransi tersebut bagi proses pembelajaran dan kehidupan sehari-hari.

\section{5) Nilai Cinta Tanah Air}

Kesenian madihin adalah sebuah kesenian tradisional merupakan salah satu media yang dapat dijadikan sebagai sarana untuk mempresentasikan nilai cinta tanah air yang dimiliki oleh manusia. Melakoni kesenian madihin atau bahkan mengapresiasi kesenian madihin akan dapat menumbuhkan rasa cinta terhadap kesenian daerah yang nantinya adalah muara cinta kepada tanah air. Oleh karena itu dapat dikatakan bahwa nilai cinta tanah air yang terkandung di dalam kesenian madihin memiliki harus dijadikan sebagai salah satu sumber nilai bagi pengembangan pendidikan karakter di Indonesia. 


\section{6) Nilai Kerja Keras}

Berdasarkan hasil penelitian dapat dinyatakan bahwa kesenian madihin mengandung nilai kerja keras di dalamnya. Nilai kerja keras tersebuat adalah salah satu alternatif untuk mengembangkan sistem pembelajaran yang dilakukan baik di sekolah maupun di luara sekolah. Nilai adalah esensi dari sebuah keinginan yang merupakan dasar manusia dalam bertindak. Tindakan yang berdasar kepada spirit kerja keras akan menghasilkan tujuan yang ingin dicapai menjadi lebih baik dan lebih maksimal. Nilai kerja keras dalam kesenian madihin tersebut dapat dijadikan sebagai contoh atau model yang harus ditiru oleh peserta didik agar dapat mengamalkan dan mempraktikan nilai tersebut baik dalam kehidupan di lingkungan sekolah dan di luar sekolah.

\section{7) Nilai Kreatif}

Kesenian madihin memiliki pola berkreatif yang sangat unik, misalnya kemampuan mengarang syair dengan spontan adalah memerlukan seseorang yang memiliki kreatifitas yang tinggi. Melagukan irama madihin sambil mengiringinya dengan tarbang adalah keseimbangan yang memerlukan latihan yang lama untuk mahir. Jadi, kesenian Madihin dapat diakatakan sebagai sebuah pola kreatifitas yang tinggi sebagai sebuah kesenian tradisional. Hal ini memiliki relevansi yang kuat dengan pendidikan karakter, karena dalam pendidikan karakter seorang peserta didik yang memiliki nilai kreatif yang tinggi akan menunjang moralitasnya kepada tindakan yang lain. Sehingga berprilaku kreatif melalui kesenian madihin telah mencerminkan upaya proses pendidikan yang diaharapkan di dalam sistem pendidikan di Indonesia.

\section{8) Nilai Komunikatif}

Nilai komunikatif yang terkandung di dalam kesenian madihin dapat kita lihat ketika seorang pamadihinan yang menampilkan madihin mampu membuat penonton merasa terlibat dalam proses pertunjukan yang disajikan. Interaksi antara penonton dengan pamadihinan inilah yang menimbulkan aspek komunikatif terjadi. Ruang komunikatif itu telah membangun sinergi yang positif antara pamadihinan dengan penontonnya. Sehingga setiap orang yang menyaksikan kesenian madihin akan merasa terlibat dan merupakan bagian dari sebuah pertunjukan juga.

\section{DAFTAR PUSTAKA}

Alfan, M. 2011. Pengantar Filsafat Nilai. Bandung: Pustaka Setia.

Deni, Junaedi. 2016. Estetika: Jalinan Subjek, Objek, dan Nilai. Yogyakarta: ArtCiv.

Djantera, Kawi,. Jarkasi; dan, Zakiah, Kusasi, Agus. 1995. Sastra Lisan Madihin. Banjarmasin: Proyek Pembinaan Bahasa dan Sastra Indonesia Daerah Kalimanantan Selatan.

Flick, Uwe. 2002. An Introduction To Qualitative Research. London: SAGE.

Frondizi, Risieri. 2011. What is Value? Terjemahkan Cuk Ananta Wijaya. Yogyakarta: Pustaka Pelajar.

Rafik, M. 2013. Laporan Penelitian : Struktur Penyajian, Bentuk, Nilai, dan Fungsi Madihin John Tralala dan Hendra. Universitas Lambung Mangkurat.

Sumasno, Hadi. 2017. Etika Banjar. Banjarmasin: ULM Press.

Thaha, M,. \& Sanderta, Bakhtiar (eds.). 2014. Pantun Madihin Lamut. Banjarmasin: Pustaka Banua.

Sunarto. 2016. "Filsafat Seni Nusantara". Imaji: Jurnal Seni dan Pendidikan Seni, 87-88, 1693-0479. 